RESEARCH ARTICLE

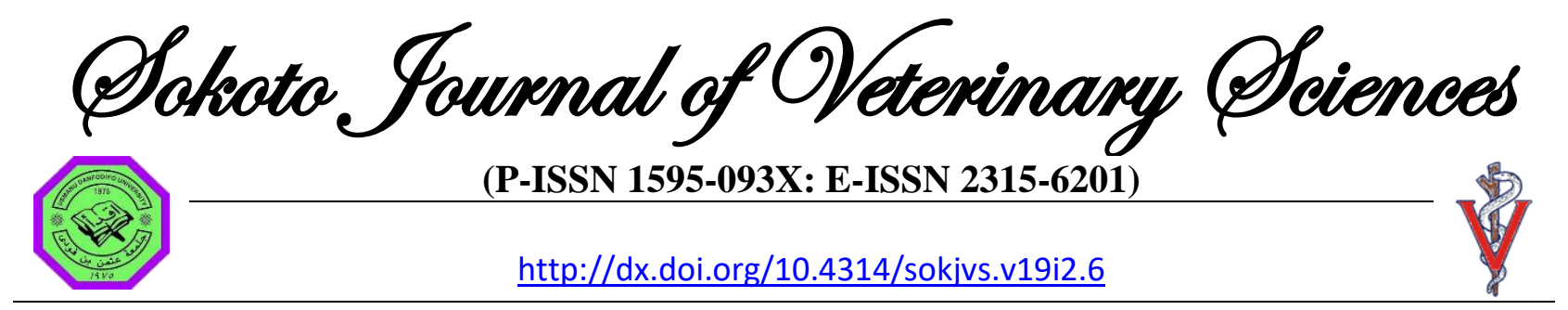

Thomas et al./Sokoto Journal of Veterinary Sciences, 19(2): 112 - 120.

\title{
Somatic cell counts and bacteria in milk from two nomadic herds in Abeokuta, Nigeria
}

\author{
FC Thomas ${ }^{1 *}$, OO Alarape ${ }^{1}$, OM Oliwo ${ }^{1}$, E Omoshaba ${ }^{2}$, OE Ojo ${ }^{2}$, JA Oyewusi ${ }^{3}$ \\ \& ES Ajibola ${ }^{1}$ \\ 1. Department of Veterinary Physiology and Biochemistry, College of Veterinary Medicine, Federal University \\ of Agriculture, Abeokuta Ogun State, Nigeria \\ 2. Department of Veterinary Microbiology, College of Veterinary Medicine, Federal University of Agriculture, \\ Abeokuta, Ogun State, Nigeria \\ 3. Department of Veterinary Pharmacology and Toxicology, College of Veterinary Medicine, Federal \\ University of Agriculture, Abeokuta, Ogun State, Nigeria
}

*Correspondence: Tel.: +2348181962523; E-mail: thomasfc@funaab.edu.ng

\begin{abstract}
Copyright: (C) 2021 Thomas et al. This is an open-access article published under the terms of the Creative Commons Attribution License which permits unrestricted use, distribution, and reproduction in any medium, provided the original author and source are credited.
\end{abstract}

Publication History: Received: 22-02-2021

Revised: 09-04-2021

Accepted: 14-04-2021

\section{Abstract}

Mastitis, the inflammation of the mammary gland, is a major endemic disease affecting dairy production worldwide. Costs of treatment and control of mastitis contributes to major losses to the dairy industry especially if the condition is not promptly and accurately diagnosed, thus necessitating the engagement of regular and reliable means of recognising intra-mammary infections. Somatic cell counting, which has been recognized as a major standard for mastitis diagnosis in milk, was utilized in this study as a direct measure of intramammary inflammation (IMI), along with bacterial culture and isolation to establish the presence of mammary infections in cows from two nomadic herds. Milk from all four quarters (composite samples) of each of 100 cows at various stages of lactation, were obtained and subjected to Levowitz-Weber staining of duplicate smears and direct microscopic counting of somatic cells. Culture and isolation of sterile milk swabs and subsequent identification by morphology, gram staining and biochemical tests were employed to assess the presence of mastitis-causing pathogens in the samples. Using $\leq 100,000$ cells $/ \mathrm{ml}$ as cut off for non-mastitic milk, sub-clinical mastitis (SM), was determined in 70 (70\%) of the examined samples. Contagious pathogens, namely; Staphylococcus aureus, Staphylococcus species and others as well as environmental bacteria, E. coli and Enterococcus species amongst others, were isolated from the samples. This result circuitously indicates the level of losses to dairy production through poor milk quality and yield, costs of treatment and culling obtainable in the nomadic dairying venture. The need for routine evaluation of raw milk and other dairy products emanating from the itinerant pastoralists, using sensitive and reliable parameters to facilitate prompt diagnosis, targeted treatment and rapid control of cow to cow or herd to herd spread of IMI is highlighted in this study. 


\section{Introduction}

The dairy industry is a thriving global enterprise that relies on the biological conversion of feed and roughages to milk and other milk-derived products for human and animal consumption. However, optimum profit from this venture is more often than not hampered by the occurrence of mammary gland inflammation, also known as mastitis. The negative impacts on the industry are either direct effects in the form of poor milk quality and yield and indirect outcomes through costs of treatment and culling to control infection (Thomas et al., 2018). A crucial step for limiting management costs associated with mastitis is a prompt and accurate diagnosis, especially of the sub-clinical form of mastitis, which does not present with obvious physical signs in either the udder tissue or milk sample (Lakshmi et al., 2014; Chakraborty et al., 2019).

Along with the substantial production of beef, cattle production in Nigeria boasts of a high turnover of dairy products such as fresh and fermented milk (nono), local cheese (wara) and milk fat (Shittu et al., 2012; Olatoye et al., 2018; Saleh et al., 2016). These have contributed immensely to upgrading the socioeconomic and financial status of most nomadic cattle farmers and their households. Indeed, dairying in the pastoral farming sector has the unique potential to improve the livelihood and income of small and medium-scale farmers and enhance the gross domestic product of the country once productivity is optimized.

The nomadic system of pastoral farming is the most common method of cattle rearing in Nigeria accounting for a vast livestock population (Reeves, 2016) and is mostly carried out by the Fulani herdsmen. Although the level of milk production in locally reared cattle can be attributed primarily to breed indisposition to dairying, another major factor that greatly contributes to low levels of milk yield from the nomadic dairy ventures is the presence of mammary gland infections or inflammation. Some reports have shown varying prevalence rates of mastitis in both intensively and nomadic/seminomadic dairy farms in several parts of Nigeria (Junaidu et al., 2011; Shittu et al., 2012; Suleiman et al., 2012; Umaru et al., 2017; Makolo et al., 2019). Most of these studies have employed the use of the cow side California Mastitis Test (CMT), an indirect test of somatic cells in milk, alone or in combination with bacteriological confirmation of causative agents of infections.

Somatic cell count (SCC) of milk samples has been considered the major marker for confirming udder inflammation and ascertaining the wholesomeness of milk (Dohoo et al., 2011). This parameter is assessed through several techniques ranging from direct microscopic counting of the cells to the more complex fossomatic and coulter counter-facilitated counting (Deb et al., 2013; Pilla et al., 2013; Souza et al., 2016). It continues to predominate as the preferred method for recognizing milk as originating from infected or uninfected mammary glands and continues to find wide usage in the dairy industry globally (Uhler, 2009; Malek dos Reis et al., 2013). As SCC is a more direct test of inflammatory markers in milk with less subjectivity, it is also widely used as a predictor of technological and storage properties of milk (Maréchal et al., 2011; Panda et al., 2019). Therefore, ascertaining the SCC of milk for mastitis determination will better help to characterize the form of mastitis through the use of previously established cut off values.

Bacterial culture and isolation are generally accepted as the most reliable method of determining the aetiologies of intramammary inflammation (IMI) (Ashraf \& Imran, 2018). Yet, the results of bacteriology alone do not indicate the extent of inflammation induced by the bacteria. Thus, supplementing SCC with bacterial culture is a more robust measurement of inflammation marking parameters and facilitates appropriate therapeutic intervention when treating IMI in milk-producing cattle.

This study aimed to determine the counts of somatic cells in milk from cows raised under nomadic management from two different herds to establish the presence of sub-clinical mastitis (SM) or clinical mastitis (CM) and species of bacteria causing the inflammation. The findings presented herein will serve as a source of data on the status of IMI and their corresponding aetiologies in these herds.

\section{Materials and Methods Sampling}

Two different temporary settlements of nomadic cattle herders were identified at Alabata village, in the suburbs of Abeokuta (Latitude: $7^{\circ} 09^{\prime} 23.40^{\prime \prime} \mathrm{N}$ and Longitude: $3^{\circ} 20^{\prime} 32.40^{\prime \prime}$ E) by ambulatory referrals. Consent to sample cattle was obtained from the pastoralists after explaining the objectives of the study. Sampling was carried out in the peak of the dry season between January and February 2018. The nomads were also engaged in oral questioning to assess their knowledge about mastitis, its incidence in their herds, as well as management 
practices employed to curb the disorder. Approximately $10 \mathrm{~mL}$ of composite milk (all quarters) was collected aseptically, after swabbing the teats with cotton wool dipped in alcohol and discarding the first striplings, from each lactating cow $(n=40$ from the first herd and $n=60$ from the second) into sterile vials. Sampling was done before the cows were milked for commercial or household milk supply. Careful physical examination of the udders for signs of inflammation was carried out before milk collection. The samples were labelled and transported in an icepack to the laboratory of the Department of Veterinary Physiology and Pharmacology, Federal University of Agriculture, Abeokuta for direct microscopic somatic cell counting. An aliquot of each sample was sent to the Veterinary Microbiology Laboratory (College of Veterinary Medicine, Federal University of Agriculture Abeokuta) for bacterial culture and isolation. All sampled animals showed no physical signs of inflammation on the udder and represented the currently lactating cows in the study herds. The physical appearance of collected milk samples was also assessed, and no signs of clinical mastitis were observed.

\section{Determination of somatic cell counts in milk}

Milk samples were analyzed for SCC using a direct microscopy method. Samples were thoroughly agitated to ensure an even mixture, then, a thin smear of $0.01 \mathrm{~mL}$ of each sample was made on a 1 $\mathrm{cm}$ diameter circle that had been manually etched on a microscopic slide and allowed to air dry. Slides were then immersed in a covered-trough containing the Levowitz-Weber (methylene blue-based) staining solution for 2 minutes (Zajac et al., 2019). The slide was drained of excess stain by resting the edge of the slide on an absorbent paper and dried. Dried stained slides were subsequently rinsed in three changes of tap water at a temperature of $35-45^{\circ} \mathrm{C}$, drained and air-dried before examination under the microscope. Counting of the stained somatic cells on the slide was done under the compound microscope with oil immersion (objective lens, $100 \mathrm{x}$ magnifications). All cells within the field were counted in duplicate slides and the average was computed and multiplied by 100 to give a total number of cells per $\mathrm{mL}$ of milk sample. Mastitis in the cows was classified on the basis of the International Diary Federation recommendation (Sharma et al., 2011) as SCC $<100,000$ cells $/ \mathrm{ml}$ (nonmastitic), 101,000-200,000 cells/ml (SM) and $>200,000$ cells/ml (CM).

\section{Bacteriological culture of milk}

At the laboratory of the Department of Veterinary Microbiology, the Federal University of Agriculture Abeokuta, culture and isolation of bacterial pathogens were carried out according to the standard protocols by making streaks of each milk sample onto blood and MacConkey agars (Oxoid, England) and allowing these to incubate under aerobic conditions at $37^{\circ} \mathrm{C}$ for $24-48$ hours. The organisms were identified based on cultural morphology, Gram's staining and biochemical analysis including sugar fermentation, catalase, oxidase, citrate, sulfide indole motility and triple sugar iron tests (Oladipo et al., 2016).

\section{Statistical analysis}

Data of SCC were checked for normality of distribution using the Kolmogorov-Smirnov and Shapiro-Wilk tests. Samples were categorized based on SCC cut-off levels as healthy and sub-clinical (Thomas et al., 2015). A Kruskal-Wallis test was used to compare the groups. $\mathrm{P}<0.05$ was set as the statistical significance value. Statistical analysis was carried out using Statistical Package For Social Sciences Software (SPSS) version 23 (IBM Inc, USA).

\section{Results}

All cows sampled were of the White Fulani breed. On physical examination of the udders of each cow and milk sample, it was observed that none showed signs of clinical mastitis (inflammation of the mammary gland and presence of clots, flakes or change in colour or consistency of milk) among the two herds. This finding was corroborated by answers of our interactive engagement with the nomads who claimed they rarely encountered any 'disease problems' of the mammary gland in their herds but also admitted to indiscriminate and un-prescribed use of drugs on their animals for other reasons. The direct microscopic counting of somatic cells in milk samples revealed a range of 44,500 to 220,000 cells per $\mathrm{mL}$ in the samples. The counts were categorized into 3 groups based on ranges prescribed to indicate 'non-mastitic', 'sub-clinical' and 'clinical mastitis' namely; 0 - 100, 000 cells/mL - healthy, 101,000 200,000 cells $/ \mathrm{mL}$ - sub-clinical mastitis and greater than 200,000 cells/mL- clinical mastitis as recommended by previous authors (Berglund et al., 2007; Schwarz et al., 2011; Thomas et al., 2015). Based on this categorization, $30 \%, 65 \%$ and $5 \%$ of 
Table 1: Descriptive statistics of the somatic cell counts analysis in three categories of the 100 samples of milk from the two nomadic herds of cattle

\begin{tabular}{|c|c|c|c|c|c|c|c|}
\hline SCC Categorization & $\%$ & $\begin{array}{l}\text { Mean } \\
(x \\
\text { cells } / \mathrm{ml})\end{array}$ & $10^{3}$ & $\begin{array}{l}\text { Median } \\
(\times \\
\text { cells/ml) }\end{array}$ & $10^{3}$ & $\begin{array}{ll}\begin{array}{l}\text { Range } \\
(\times\end{array} & 10^{3} \\
\text { cells } / \mathrm{ml}) & \end{array}$ & $\begin{array}{l}\text { S Deviation } \\
\left(\times 10^{3} \text { cells } / \mathrm{ml}\right)\end{array}$ \\
\hline $\begin{array}{l}0-100 \times 10^{3} \text { cells } / \mathrm{mL} \text { (non-mastitic } \\
\text { cows) }\end{array}$ & 30 & 80.6 & & 86.5 & & $44.5-98$ & 14.9 \\
\hline $\begin{array}{l}101-200 \times 10^{3} \text { cells } / \mathrm{mL} \text { (sub clinical } \\
\text { mastitis) }\end{array}$ & 65 & 129.5 & & 124.5 & & $100-199$ & 24.5 \\
\hline$>200 \times 10^{3}$ cells $/ \mathrm{mL}$ (clinical mastitis) & 5 & 210.7 & & 212.0 & & $202.5-220.5$ & 7.4 \\
\hline
\end{tabular}

Table 2: Categorization of milk samples based on SCC levels and the various species of bacteria isolated in the categories from the 100 milk samples from two nomadic herds in Abeokuta

\begin{tabular}{|c|c|c|c|c|}
\hline $\begin{array}{l}\text { SCC } \\
\text { Category }\end{array}$ & $\begin{array}{l}\text { Total } \\
\text { No }\end{array}$ & $\begin{array}{l}\text { Number of (different) } \\
\text { species per sample }\end{array}$ & $\begin{array}{l}\text { Major bacteria isolated (and } \\
\text { number of samples in which } \\
\text { isolated) }\end{array}$ & $\begin{array}{l}\text { Other species isolated and No } \\
\text { of samples in which they were } \\
\text { co-isolated }\end{array}$ \\
\hline $\begin{array}{l}0-100 \times \\
10^{3} \text { cells } / \mathrm{m} \\
L \quad \text { (healthy } \\
\text { milk) }\end{array}$ & 30 & $\begin{array}{l}20 \text { samples had } 2 \text { species } \\
8 \text { samples had } 1 \text { species } \\
1 \text { sample had } 0 \text { species } \\
1 \text { sample had } 3 \text { species }\end{array}$ & 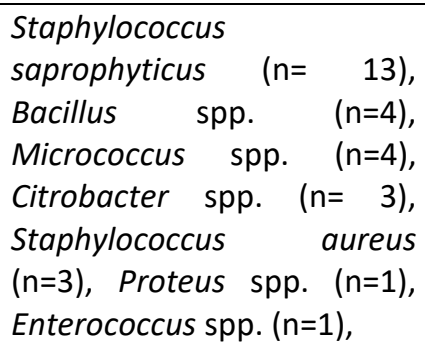 & $\begin{array}{ll}\text { Staphylococcus } & \text { saprophyticus } \\
(\mathrm{n}=6), & \text { Staphylococcus } \\
\text { spp. }(\mathrm{n}=5), & \text { Staphylococcus } \\
\text { aureus }(\mathrm{n}=4), & \text { Micrococcus spp. } \\
(\mathrm{n}=4), \quad \text { Bacillus spp. } \quad(\mathrm{n}=1), \\
\text { Enterococcus spp. }(\mathrm{n}=1)\end{array}$ \\
\hline $\begin{array}{l}101-200 \\
\times \quad 10^{3} \\
\text { cells } / \mathrm{mL} \\
\text { (sub- } \\
\text { clinical } \\
\text { mastitis) }\end{array}$ & 65 & $\begin{array}{l}42 \text { samples had } 2 \text { species } \\
18 \text { samples had } 1 \text { species } \\
4 \text { samples had } 3 \text { species } \\
1 \text { sample had } 0 \text { species }\end{array}$ & 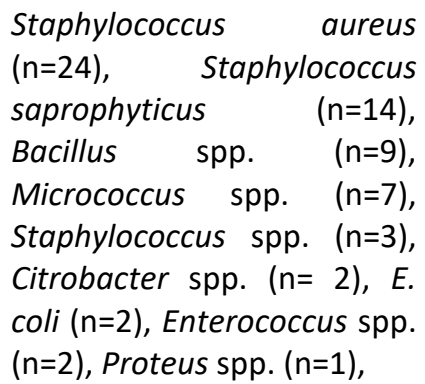 & $\begin{array}{l}\text { Micrococcus spp. } \quad(n=12), \\
\text { Staphylococcus spp. }(\mathrm{n}=11), \\
\text { Staphylococcus saprophyticus } \\
(\mathrm{n}=10), \text { Staphylococcu saureus } \\
(\mathrm{n}=9), \text { Enterococcus spp. }(\mathrm{n}=5) \text {, } \\
\text { Bacillus spp. }(\mathrm{n}=2)\end{array}$ \\
\hline $\begin{array}{l}\text { Greater } \\
\text { than } 200 \times \\
10^{3} \\
\text { cells } / \mathrm{mL} \\
\text { (clinical } \\
\text { mastitis) }\end{array}$ & 5 & $\begin{array}{l}3 \text { samples had } 2 \text { species } \\
2 \text { samples had } 1 \text { species }\end{array}$ & $\begin{array}{l}\text { Staphylococcus aureus } \\
(\mathrm{n}=2), \quad \text { Staphylococcus } \\
\text { saprophyticus } \quad(\mathrm{n}=1), \\
\text { Staphylococcus spp. }(\mathrm{n}=1), \\
\text { Micrococcus spp. }(\mathrm{n}=1)\end{array}$ & $\begin{array}{l}\text { Staphylococcus aureus }(\mathrm{n}=1) \text {, } \\
\text { Staphylococcus saprophyticus } \\
(\mathrm{n}=1) \text {, Staphylococcus spp. }(\mathrm{n}=1)\end{array}$ \\
\hline
\end{tabular}

the cows were non-mastitic, sub-clinically mastitic and clinically mastitic respectively (composite udder milk) as shown in Table 1. The distribution of SCC (type of mastitis) for each herd is shown in the chart in Figure 1.

\section{Bacterial culture and isolation}

In this study, Staphylococcus spp. were the most prevalent bacteria in the milk samples and were isolated as the major bacterial species from 61 of the raw milk samples. Twenty-nine (29) (47\%), 28 (46\%) and 4 (7\%) were Staphylococcus aureus, Staphylococcus saprophyticus and other uncharacterized Staphylococcus (Staphylococcus spp.), respectively. Micrococcus, Bacillus, Enterococcus, Citrobacter and Proteus spp. were isolated as the primary species in 12,13 , three, five and two of the samples, respectively. Escherichia coli was isolated from two (2\%) samples and two of the samples showed no growth. Distributions of bacteria 
identified in the two herds are displayed in Figure 1. A single species was isolated from $27 \%$ of the samples, while two and three different species were seen from $66 \%$ and $5 \%$ of the samples, respectively. The most common combination of species was that of Staphylococcus aureus and Staphylococcus saprophyticus. The distribution of types and number bacterial species identified per milk samples from the two herds are shown in figures 2 and 3 respectively.

In comparing the SCC categories with the species and number of different species seen in samples, Table 2 summarizes the observations from this study. A Kruskal-Wallis analysis of the samples showed no significant differences $(P=0.818)$ in the somatic cell counts by category or the number of bacteria species isolated in them. A boxplot is shown in Figure 4.

\section{Discussion}

While the search for more sensitive and field adaptable markers of mastitis continues, counting of somatic cells in milk remains an accepted standard for the diagnosis of bovine mastitis, serious welfare and economic burden on the dairy industry worldwide. Therefore, the target of this cross-sectional study was to investigate the presence of mastitis from nomadically raised cows transiting through the Southwest city of Nigeria: Abeokuta, by SC counting and confirming the likely etiologies using bacteriology. The results will potentially provide reliable information on the status of subclinical and clinical mastitis of this agricultural venture within this region. An SCC range of 44,500 to 220,000 cells $/ \mathrm{mL}$ as seen from this study can be concluded to be generally low and indicative of the low prevalence of clinical infections in the udders of cows in these farms (given that the presence of mastitis in the gland has the potential of increasing SCC to up to $1,000,000$ cells $/ \mathrm{mL}$ (Sharma et al., 2011)). This finding is also supported by the absence of signs of mastitis upon physical examination of either the udder or milk. However, bacterial culture and isolation indicated that potentially infective agents were present in most samples. Approved cut off levels of SCC in milk for delineation of sub-clinical from clinical mastitis varies from country to country. However, the international dairy federation has

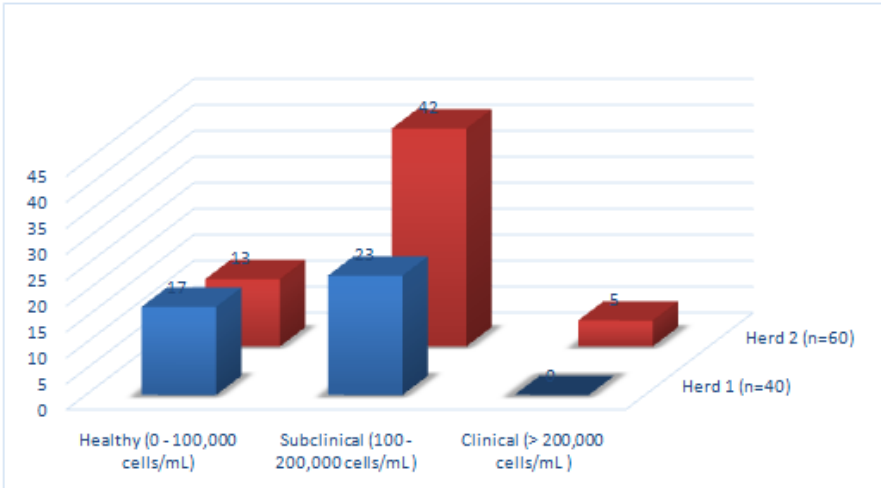

Figure 1: Herd distribution of somatic cell counts per mastitisindicating categories of milk samples 
examined in the present study were indicative of clinical mastitis although no signs of clinical disease were observed. This finding highlights potential unreliability and the subjectivity of physical examination as well as discrepancies in SCC response of cows in these herds (or the general region) to bacterial invasion. Confounding effects of additional factors require further investigation, and re-categorization of SCC numbers to adequately reflect variation with the form of mastitis and health is warranted.

Most studies in Nigeria have focused on the use of the California Mastitis Test (CMT) for confirmation of SM (Ameh et al., 1999; Shittu et al., 2012; Makolo et al., 2019). The advantage of speed and ease of execution and field (cow-side) applicability support its popular use, however, the test has a major limitation of being subjective as it is an indirect test. There has been a renewed call for the use of SCC determination in mastitis monitoring (Adamu et al., 2020) that has been reported by only a few workers in Nigeria (Ahaotu et al., 2013; Olatoye et al., 2018). Apart from indicating mastitis presence and direct production losses, High SCC has been associated with milk of low quality that deteriorates easily. Thus, there is a need to incorporate the assessment of SCC in dairy production and management in Nigeria.

From this study, $65 \%$ of sampled cows had subclinical mastitis. This deviates largely from levels of sub-clinical mastitis reported by some workers such as 19.7\% (Umaru et al., 2019), 23.9\% (Umaru et al., 2017), 30.9\% (Suleiman et al., 2012) who studied the situation in other parts of Nigeria. These variations may be related to the use of CMT for sub-clinical mastitis determination as opposed to SCC used in the present study as well as other cow and management factors. However, the prevalence of sub-clinical mastitis here nears that reported by Shittu et al. (2012) who reported a cow level prevalence of $85.3 \%$. However, CMT was also utilized in that study. This result agrees more with the physical examination as well as bacterial culture and isolation, where no signs of clinical mastitis were observed despite widespread isolation of potentially pathogenic bacteria in the samples that occurred. Invariably, the high prevalence of sub-clinical mastitis in the two herds is an indication of levels of production losses in the form of poor milk yield (Sharma et al., 2011) obtained in these herds. Indeed, in an earlier report, production losses have

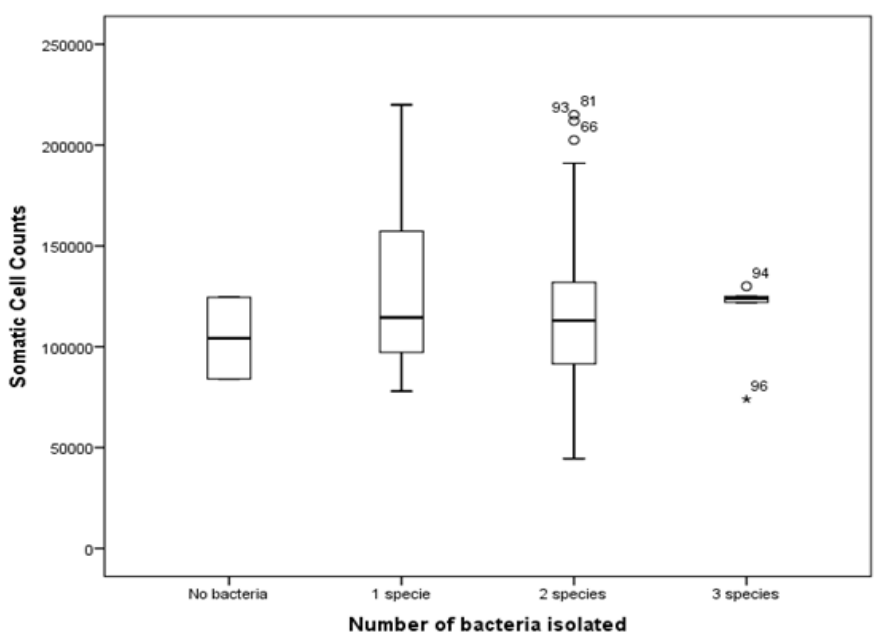

Figure 2: Boxplot showing the levels of somatic cell counts in samples by number of different bacteria species isolated from them

been shown to occur in milk having an SCC of 100,000 cells/ml and above (Sharma et al., 2011).

Bacteria were isolated from $98 \%$ of the samples. Among these, there is a high likelihood of contamination by teat commensals rather than true infection of the mammary gland. Isolated organisms may be false-positive indicators, hence there is a need to interpret the culture results in conjunction with actual signs of inflammation (active infection) which is SCC in this case (Souza et al., 2016). Thus the results of this study emphasize the importance of measuring inflammatory indicators along with aetiological agents in confirming the occurrence of mastitis as previously suggested (Kelly et al., 2011). The isolation of more than one species of bacteria in about $70 \%$ of the sample is also suggestive of a high contamination rate by one or more of the species isolated, especially as SCC in samples with multiple species showed no significant difference from those with one species detected. Since the release of somatic cells is an innate immune response to the invasion of the mammary gland, it would be expected that SCC increases in response to the magnitude of species colonizing the gland. As has been frequently reported in Nigeria and many other parts of the world, Staphylococcus aureus was the most common pathogen found to cause mastitis in the two farms under this study (Ameh et al., 1999; Bradley et al., 2007; Suleiman et al., 2018). Because of its contagious nature, high prevalence and chronicity, S. aureus infections prevail in most dairy herds with frequent manifestation as sub-clinical mastitis, which can also explain the reason for the high level of sub-clinical mastitis in the herds. 
Additionally, drug resistance has been implicated among some $S$. aureus strains which have been explored in several studies (Haveri et al., 2007; Suleiman et al., 2012; Elhaig \& Selim, 2014; Ugwu et al., 2015). Prevalence of other major mastitiscausing-pathogens, especially the environmental pathogen, E. coli (2\%), was low in the study. This may presumably be a result of it being an 'environmental' bacterium of enteric origin, which demands its presence on environmental matrices such as beddings, floors or milking utensils where the organisms have the opportunity to multiply and then infect the glands. The transhumance characteristics of nomadic cattle herders, however, obviate this potential as animals do not stay in specific locations long enough due to the need to graze to other locations in search of fresh pasture and or water (Ducrotoy et al., 2016). The prevalence of coliforms (E. coli and Enterococcus spp) in these two herds was $5 \%$, which was lower compared to previous reports of $8.2 \%$ by (Makolo et al., 2019), 10.3\% (Mbuk et al., 2016) and several others. The occurrence of these environmental pathogens may also be largely influenced by climate or weather conditions, with higher incidence during the wet humid (as against dry) weather favours bacterial propagation. The study area, Abeokuta, is located in the Southwest of Nigeria, having a rainforest climate with long periods of rainfall and more vegetation and water sources that favour the migration of cattle rearers during the dry spell period (November to March) in the northern region of Nigeria. Thus, animals may only have seasonal exposure to certain locations in some cases. However, grazing of specific lands by different herds within short intervals may predispose animals to infections from these areas.

The direct microscopic method for evaluation of the SCC in milk as utilized in the present study is a largely obsolete, laborious and time-consuming procedure and has been replaced in most developed countries with fully automated techniques such as fossomatic and coulter counters (Kelly et al., 2011). Other more recently developed milk analyzers have been in use for several decades and are becoming more affordable. Setting up of milk screening stations by the acquisition of this modern equipment would facilitate ready and comprehensive screening of milk samples, and thus would be of immense benefit to the dairy industry development if adopted to provide milk recording services for optimizing wholesome dairy production in Nigeria.

A limitation of this study that may have confounded the SCC results is the analysis of composite rather than quarter level milk, as SCC levels in an infected quarter(s) may be diluted by milk from other uninfected quarters of the same udder. It would therefore be beneficial and recommended to assess SCC in quarter milk samples from nomadic herds to give a clearer picture of prevalence and SCC range in quarter milk from this system of dairying.

Overall, this study has shown the value of SCC in determining the udder health of cows raised under the nomadic system. It is recommended that this procedure be harnessed through the use of modern somatic cell counters and incorporated into dairy development programs in Nigerian to facilitate prompt control of mastitis. However, as reported by Thomas et al. (2015) and others, cow factors such as parity number could affect the SCC. Therefore, to improve the diagnostic value of composite milk SCC, the counts should be adjusted with specific cow factors as prescribed by (Nyman et al., 2014). Judging from the high prevalence of mastitis in the nomadic herds as seen in the present study (70\%) and the prevalence of multiple bacterial infections in these systems, it is recommended that a standard ranching system should be provided to reduce the impact of disease in dairy production in Nigeria.

\section{Acknowledgements}

The authors wish to acknowledge the technical assistance of staff in the Veterinary Physiology and Veterinary Microbiology laboratories, Federal University of Agriculture, Abeokuta.

\section{Conflicts of Interest}

The authors declare no conflict of interest.

\section{References}

Adamu HO, Hussaini RO \& Obasuyi C (2020). Prevalence of mastitis in Nigerian livestock: A Review. Open Vets, doi.10.1515/ovs2020-0101.

Ahaotu EO, Madubuike FN \& Ifuk OJ (2013). Smallholder dairy production in Southern Nigeria: Production, management and milk quality problems. International Journal of Agriculture and Biosciences, 2(2): 76-81

Ameh JA, Edgbe-Nwiyi T \& Zaria LT (1999). Prevalence of bovine mastitis in Maiduguri Borno State, Nigeria. Veterinarski Arhiv, 69(2): 87-95.

Ashraf A \& Imran M (2018). Diagnosis of bovine mastitis: from laboratory to farm. Tropical Animal Health Production, 50(6): 11931202. 
Berglund I, Pettersson G, Ostensson K \& Svennersten-Sjaunja K (2007). Quarter milking for improved detection of increased SCC. Reproduction in Domestic Animals, 42(4): 427-432.

Bradley A, Leach K, Breen J, Green L \& Green M (2007). Survey of the incidence and aetiology of mastitis on dairy farms in England and Wales. Veterinary Record, 160(8): 253-258

Chakraborty S, Dhama K, Tiwari R, Iqbal M \& Kumar S (2019). Technological interventions and advances in the diagnosis of intramammary infections in animals with emphasis on bovine population - A Review. Vet. Quarterly, 39(1): 76-94.

Deb R, Kumar A, Chakraborty S, Verma AK, Tiwari R, Dhama K, Singh U \& Kumar S (2013). Trends in diagnosis and control of bovine mastitis: A review. Pakistan J. Biol. Sciences, 16(23): 1653-1661.

Dohoo I, Smith J, Andersen S, Kelton D \& Godden S (2011). Diagnosing intramammary infections: Evaluation of definitions based on a single milk sample. Journal of Dairy Science, 94(1): 250-261

Ducrotoy MJ, Majekodunmi AO, Shaw APM, Bagulo H, Musa UB, Bertu WJ, Gusi AM, Ocholi RA, Bryssinckx W \& Welburn SC (2016). Fulani cattle productivity and management in the Kachia Grazing Reserve, Nigeria. Pastoralism, doi.10.1186/s13570-016-0072$\mathrm{y}$.

Elhaig MM \& Selim A (2014). Molecular and bacteriological investigation of sub-clinical mastitis caused by Staphylococcus aureus and Streptococcus agalactiae in domestic bovids from Ismailia, Egypt. Tropical Animal Health and Production, 47(2): 271-276.

Haveri M, Roslöf A, Rantala L \& Pyörälä S (2007). Virulence genes of bovine Staphylococcus aureus from persistent and nonpersistent intramammary infections with different clinical characteristics. Journal of Applied Microbiology, 103(4): 993-1000.

Junaidu AU, Salihu MD, Tambuwala FM, Magaji AA \& Jaafaru S (2011). Prevalence of Mastitis in Lactating Cows in some selected Commercial Dairy Farms in Sokoto Metropolis. Advances in Applied Science Research, 2(2): 290-294.

Kelly AL, Leitner G \& Merin U (2011). Milk quality and udder health: Test methods and standards. Encyclopedia of Dairy Sciences, Second edition (John W. Fuquay, Editor), Academic Press UK. Pp 894-901.

Lakshmi R, Thanislass J, Antony PX \& Mukhopadhyay HK (2014). Haptoglobin gene expression in spontaneous bovine sub-clinical mastitis caused by staphylococcus and coliforms microbes. Animal Science Reporter, 8(1): 917.

Makolo D, Suleiman A \& Olonitola O (2019). Prevalence of Mastitis in Lactating Bovines and Associated Coliforms Among Selected Pastoral Herds in Parts of Kaduna State, Nigeria. Academic Journal of Life Sciences, 5(1): 1-9.

Malek dos Reis, CB, Barreiro JR, Mestieri L, Felicio Porcionato MA de \& dos Santos MV (2013). Effect of somatic cell count and mastitis pathogens on milk composition in Gyr cows. BMC Veterinary Research, doi.10.1186/1746-6148-9-67.

Maréchal L, Loir L, Le Maréchal C, Thiéry R, Vautor E, Le Loir $Y$, Le Maréchal $C$, Le Loir $Y$ \& Thiéry R (2011). Mastitis impact on technological properties of milk and quality of milk products-a review. Dairy Science and Technology, 91(3): 247-282.

Mbuk EU, Kwaga JKP, Bale JOO, Boro LA \& Umoh JU (2016). Coliform organisms associated with milk of cows with mastitis and their sensitivity to commonly available antibiotics in Kaduna State, Nigeria. Journal of Veterinary Medicine and Animal Health, 8(12): 228-236.

Nyman AK, Persson WK, Bennedsgaard TW, Larsen, T \& Emanuelson $U$ (2014). Associations of udder-health indicators with cow factors and with intramammary infection in dairy cows. Journal of Dairy Science, 97(9): 54595473.

Oladipo OO, Ayo JO, Ambali SF \& Mohammed B (2016). Evaluation of hepatorenal impairments in Wistar rats coexposed to low-dose lead, cadmium and manganese: insights into oxidative stress mechanism. Toxicological Mechanisms and Methods, 26(9): 674-684.

Olatoye O, Amosun A, Ogbu U \& Okunlade Y (2018). Bulk tank somatic cell count and associated microbial quality of milk from selected dairy cattle herds in Oyo state, Nigeria. Italian Journal of Food Safety, 7(2): 95-100. 
Panda BSK, Mohapatra SK, Alhussien MN \& Dang AK (2019). Amount of milk neutrophil percentage and associated CD molecular changes on the compositional and technological properties of milk. The Open Biotechnology Journal, 13(1): 129-136.

Pilla R, Malvisi M, Snel GGM, Schwarz D, König S, Czerny CPP \& Piccinini R (2013). Differential cell count as an alternative method to diagnose dairy cow mastitis. Journal of Dairy Science, 96(3): 1653-1660.

Reeves F (2016). Transhumance or sedentarization of nomadic herders: What future for a sustainable livestocking in the Tubah Uplands, North West Cameroon. International Journal of Advancement in Remote Sensing, GIS and Geography, 4(1): 42-52.

Saleh MK, Atala T, Omokore DF, Ahmed B, Ali FS \& Kajang G (2016). Performance of Improved Dairy Cattle Technologies Among Farmers in Northern Nigeria. Journal of Agricultural Extension, 20(1): 1-12.

Schwarz D, Diesterbeck US, König S, Brügemann K, Schlez K, Zschöck M, Wolter W \& Czerny CP (2011). Microscopic differential cell counts in milk for the evaluation of inflammatory reactions in clinically healthy and subclinically infected bovine mammary glands. Journal of Dairy Research, 78(4): 448-55.

Sharma N, Singh NK \& Bhadwal MS (2011). Relationship of Somatic Cell Count and Mastitis: An Overview. Asian-Australian Journal of Animal Science, 24(3): 429-438.

Shittu A, Abdullahi J, Jibril A, Mohammed AA \& Fasina FO (2012). Sub-clinical mastitis and associated risk factors on lactating cows in the Savannah Region of Nigeria. BMC Veterinary Research, doi.10.1186/17466148-8-134.

Souza FN, Cunha AF, Rosa DLSO, Aparecida M, Brito V, Guimarães AS, Mendonça LC, Guilherme $N$, Lage AP, Blagitz MG, Libera AMMPD, Marcos B \& Cerqueira MMOP (2016). Somatic cell count and mastitis pathogen detection in composite and single or duplicate quarter milk samples. Pesquisa Veterinaria Brasileira, 36(9): 811-818.

Suleiman AB, Umoh VJ, Kwaga JKP \& Shaibu SJ (2012). Prevalence and antibiotic resistance profiles of Methicillin resistant Staphylococcus aureus (MRSA) isolated from bovine mastitic milk in Plateau State, Nigeria. International Research Journal of Microbiology, 2(8): 264-270.

Suleiman TS, Karimuribo ED \& Mdegela RH (2018). Prevalence of bovine sub-clinical mastitis and antibiotic susceptibility patterns of major mastitis pathogens isolated in Unguja island of Zanzibar, Tanzania. Tropical Animal Health and Production, 50(2): 259-266.

Thomas FC, Geraghty T, Simões PBA, Mshelbwala FM, Haining H \& Eckersall PD (2018). A pilot study of acute phase proteins as indicators of bovine mastitis caused by different pathogens. Research in Veterinary Science, 119(8): 176-181.

Thomas FC, Waterston M, Hastie P, Parkin T, Haining $H$ \& Eckersall PD (2015). The major acute phase proteins of bovine milk in a commercial dairy herd. BMC Veterinary Research, 11(1): 207

Ugwu C, Gomez-Sanz E, Agbo I \& Torres C (2015). Characterization of mannitol-fermenting methicillin-resistant staphylococci isolated from pigs in Nigeria. Brazilian Journal of Microbiology, 46(3): 7.

Uhler C (2009). Mastitis in Dairy Production: Estimation of Sensitivity, Specificity and Disease Prevalence in the Absence of a Gold Standard. Journal of Agricultural, Biological, and Environmental Statistics, 14(1): 79-98.

Umaru GA, Kwaga JKP, Bello M, Raji MA \& Maitala YS (2017). Occurrence of bovine mastitis and isolation of staphyloccocus species from fresh cow milk in settled Fulani herds in Kaduna state, Nigeria. Bayero Journal of Pure and Applied Sciences, 10(1): 259-263.

Zajac P, Capla J \& Golian J (2019). Direct Microscopic Somatic Cell Count. Key Publishing Pp 516. 